\title{
Can bacterivory alone sustain larval development in the polychaete Hydroides elegans and the barnacle Balanus amphitrite?
}

\author{
Louis A. Gosselin*, Pei-Yuan Qian** \\ Department of Biology, Hong Kong University of Science and Technology, Clear Water Bay, Kowloon, Hong Kong
}

\begin{abstract}
Although recent studies have found that some invertebrate larvae can meet part of their metabolic needs through bacterivory, it is unclear to what extent bacterivory can compensate for reduced phytoplankton abundance. The present study determined whether larvae of a polychaete (Hydroides elegans) and a barnacle (Balanus amphitrite) can survive, grow, and develop to competence solely on a diet of bacteria. In laboratory experiments, $H$. elegans larvae provided with bacteria as their sole particulate food source completed larval development, attached, and metamorphosed into healthy early juveniles. In addition, several of these juveniles, when provided with phytoplankton after metamorphosis, developed to maturity and spawned viable offspring. Bacterial abundances measured in Port Shelter, a bay in Hong Kong waters where organisms for the present study were collected, would not sustain maximum development rates of $H$. elegans larvae. However, bacterial abundances were sufficiently high and consistent over time to constitute a reliable food source. Consequently, starvation may not be a direct cause of larval mortality in this species. On the other hand, B. amphitrite larvae provided wath bacteria did not grow, and death occurred at the same age as in starved larvae, suggesting they cannot use bacteria as a supplementary food source. Available data suggests that most barnacle recruitment in Hong Kong waters occurs when phytoplankton abundance reaches peak levels. Recruitment of $H$. elegans, however, occurs throughout the year, suggesting that spawning and successful larval development may be independent of phytoplankton availability, and that larvae largely rely on alternate food sources such as bacteria.
\end{abstract}

KEY WORDS: Bacteria - Growth Survival - Size at competence - Larval development Feeding Starvation

\section{INTRODUCTION}

Most planktotrophic invertebrate larvae readily use phytoplankton as a food source, and are typically reared for research or aquaculture on a diet of phytoplankton. Organic matter, however, is also available to larvae in various other forms in the water column, including dissolved matter (DOM), inert particles, bacteria, cyanobacteria, protozoa, and zooplankton. Several non-phytoplanktonic sources of organic matter can be used as food by at least some larvae (e.g. DOM: Jaeckle \& Manahan 1989, Hoegh-Guldberg 1994;

\footnotetext{
- Present address: Department of Biology, University College of the Cariboo, Kamloops, British Columbia, Canada $\mathrm{V} 2 \mathrm{C} 5 \mathrm{~N} 3$

- Addressee for correspondence.

E-mail: boqianpy@usthk.ust.hk
}

cyanobacteria: Okaji et al. 1997; protozoa: Baldwin \& Newell 1991; detritus: Qian \& Chia 1990). Bacteria, the focus of the present study, are ingested and assimilated by certain echinoderm larvae (Rivkin et al. 1986 , Pearse et al. 1991) and by bivalve larvae (Chalermwat et al. 1991, Douillet 1993a, b).

The importance of non-phytoplanktonic forms of organic matter as food sources is of particular interest for understanding feeding and energy sources. Since planktotrophic larvae in many regions may encounter phytoplankton abundances that are insufficient to sustain survival and growth, bacteria have been suggested as a supplementary source of organic matter (Crisp et al. 1985, Rivkin et al. 1986, Olson 1987, Douillet \& Langdon 1993) and nutrients (Phillips 1984, Baldwin \& Newell 1995). This hypothesis is supported by studies showing that bivalve larvae can obtain enough 
energy through bacterivory to meet a portion of a larva's metabolic needs (Chalermwat et al. 1991, Douillet 1993b), and that growth and survival are enhanced when certain strains of bacteria are added to phytoplankton cultures used to feed larvae (Martin \& Mengus 1977, Douillet \& Langdon 1993). Few studies, however, have specifically examined the potential of bacterivory for supporting larval survival, growth, and development. In particular, it is unclear to what extent bacteria can support larvae when phytoplankton is scarce.

This study determines whether bacteria can be used as a food source by larvae of a polychaete (Hydroides elegans) and a barnacle (Balanus amphitrite). Specifically, we examine whether larvae of these species can use bacteria to sustain survival, growth, and development to competence.

\section{MATERIALS AND METHODS}

Study organisms and general methods. Hydroides elegans and Balanus amphitrite are common in Hong Kong coastal waters (Morton \& Morton 1983) and are widely distributed throughout the world (Costlow \& Bookhout 1958, Hadfield et al. 1994). Gametes are released and fertilization is external in $H$. elegans, whereas adult $B$. amphitrite release offspring as nauplius larvae. In these species, planktonic larval development, attachment, and metamorphosis are completed within 4 to $8 \mathrm{~d}$ when phytoplankton is abundant (Qiu \& Qian 1997a, b). For the present study, adults of both species were collected from Port Shelter, a bay in eastern Hong Kong waters (Fig. 1).

To obtain Hydroides elegans larvae, 3 to 6 adult worms of each sex were induced to release gametes by cracking their tubes at mid-body position (Hadfield et al. 1994). An aliquot of sperm suspension was mixed with the oocytes for 5 to $10 \mathrm{~min}$. Final sperm concentration was not monitored, as $H$. elegans oocytes are successfully fertilized under a wide range of sperm concentrations (Pechenik \& Qian in press). The remaining sperm were then removed by filtering the suspension through a $25 \mu \mathrm{m}$ screen and rinsing the eggs in a bath of $0.22 \mu \mathrm{m}$ filtered seawater (FSW). The eggs were then placed in a beaker with FSW for $\sim 24 \mathrm{~h}$ to allow development to the trochophore stage.

Adult Balanus amphitrite released nauplius I larvae when exposed to bright light. Since barnacle larvae develop through the nauplius I stage without feeding (R. R. Strathmann 1987), newly released larvae were placed in FSW for $\sim 12$ h to allow development to nauplius II.

For Expts 3 and 4, described below, antibiotics were added to seawater for the first $24 \mathrm{~h}$ (Hydroides ele-

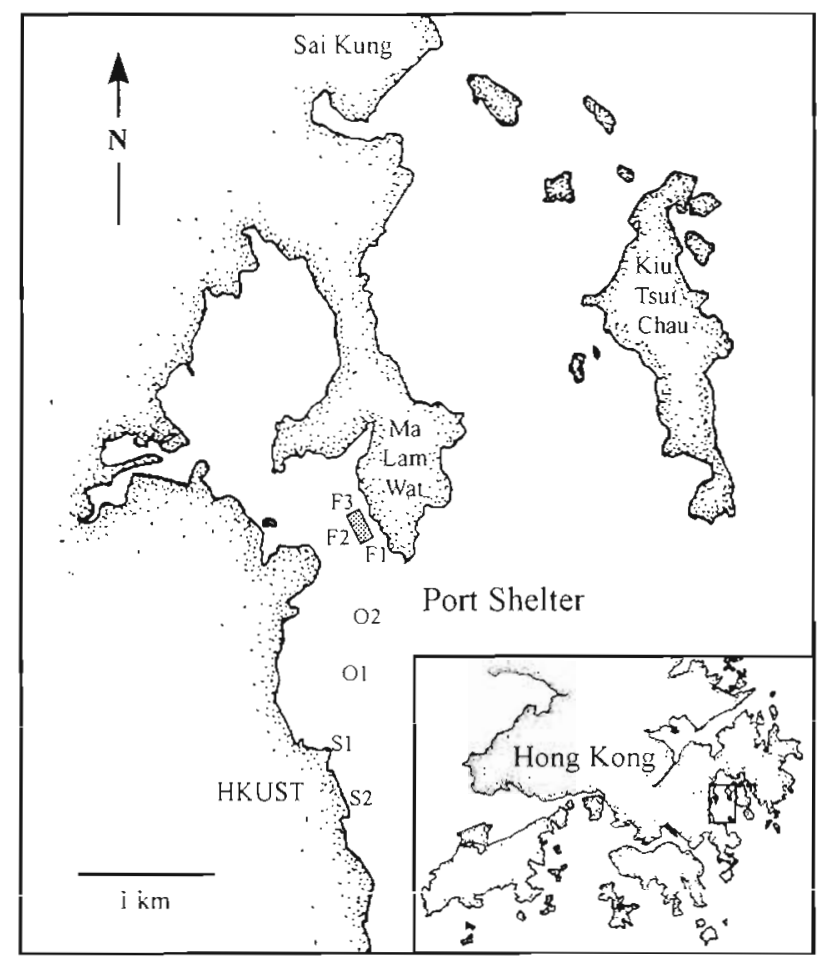

Fig. 1. Map of Port Shelter, Hong Kong, showing sampling sites in the 3 areas for which bacterial concentrations were determined. Stns S1 and S2 are nearshore stations, with S1 being located at the pier of the Hong Kong University of Science and Technology (HKUST); $\mathrm{O} 1$ and $\mathrm{O} 2$ are of shore stations. Stns F1 to F3 were located at the perimeter of a fish farm operation (囦)

gans) or $12 \mathrm{~h}$ (Balanus amphitrite) of development after spawning. The solution consisted of $150 \mu \mathrm{g} \mathrm{m}^{-1}$ Streptomycin sulphate and $100 \mu \mathrm{g} \mathrm{m}^{-1}$ Penicillin G sodium salt. All larvae were then rinsed in untreated FSW before transferring to one of the treatments. For size measurements, larvae were anaesthetized in a solution of 10 to $20 \%$ ethanol in seawater; these larvae were discarded after measurements. During the experiments, larvae were kept in incubators at 22 to $23^{\circ} \mathrm{C}$

Bacterial concentrations. Field concentrations: To characterize bacterial availability to larvae in local waters, bacterial concentrations (cells $\mathrm{ml}^{-1}$ ) were determined for surface seawater samples collected monthly at 7 sites from October 1996 to June 1997. The sites (Fig. 1) were located in Port Shelter, which supports populations of both study species, and were distributed among 3 areas: 2 sites were nearshore locations close to the Hong Kong University of Science and Technology, 3 sites were on the opposite side of the bay at the perimeter of a fish farming operation, and 2 offshore sites were located part way between the university and the fish farm (Fig. 1). Seawater samples 
were collected during the last week of each month at a depth of 20 to $40 \mathrm{~cm}$ and were immediately preserved with $0.22 \mu \mathrm{m}$ filtered, buffered formaldehyde to final concentrations of $3.75 \%$ formaldehyde. Within $3 \mathrm{~d}$ of sampling, and in most cases within $24 \mathrm{~h}$, a subsample of each formaldehyde-treated seawater sample was stained with Acridine Orange and filtered onto a polycarbonate filter. The procedures used to stain, filter, and subsequently count bacteria were as described by Turley (1993) and by Suzuki et al. (1993). When sampling, water temperature was measured and an additional untreated seawater sample was collected from one nearshore site for salinity measurements.

Concentrations in treatment suspensions: The staining and counting procedures described above were also used to quantify bacterial concentrations in treatment suspensions. In Expts 1 and 2, bacterial concentrations in the treatment suspensions were determined only once, prior to adding larvae. In Expts 3 and 4, concentrations were determined once prior to adding larvae and again 1 d later, immediately after larvae were removed and transferred to new suspensions, as larvae were transferred to new suspensions every day.

Preparation of food treatments. The experiments described below included 3 food treatments: phytoplankton, bacteria, and control. The phytoplankton treatment served to assess larval performance in conditions of abundant phytoplankton supply, whereas the control treatment served to assess larval performance in the absence of phytoplankton and with minimal bacteria.

The dinoflagellate Isochrysis galbana (Tahitian) was provided in the phytoplankton treatments of the $\mathrm{Hy}$ droides elegans experiments, whereas the diatom Thalassiosira pseudonana was provided in the Balanus amphitrite experiment. All phytoplankton were grown in $\mathrm{f} / 2$ medium; cultures were not axenic. Phytoplankton treatment suspensions were prepared by centrifuging a sample of the phytoplankton culture at $1100 \times g$, pipetting out the supernatant, and resuspending the cells in autoclaved artificial seawater (MBL general purpose formula; Bidwell \& Spotte 1985, M. F. Strathmann 1987) at $32 \%$ salinity. The resulting phytoplankton treatment suspensions contained $10^{5}$ to $10^{6}$ cells $\mathrm{ml}^{-1}$.

Bacteria treatment suspensions contained 4 strains of heterotrophic marine bacteria obtained and isolated from surface water in Port Shelter, and consisted of cocci (1 strain) and short rods ( 3 strains) (S. Lau pers. comm.). Original stocks of each strain were maintained separately in autoclaved nutrient broth $\left(25 \mathrm{~g} \mathrm{l}^{-1}\right.$, Nutrient Broth No. 2, Oxoid Inc.). One ml of each of the 4 stock suspensions and an additional $1 \mathrm{ml}$ of sterilized nutrient broth were placed together in $400 \mathrm{ml}$ of FSW (final suspension contained $1.25 \%$ of recommended nutrient broth concentration) and incubated at $30^{\circ} \mathrm{C}$. Such a bacterial culture was used to prepare treatment suspensions only twice, at 24 and $48 \mathrm{~h}$ after inoculation; new bacterial cultures were prepared every $2 \mathrm{~d}$. To prepare bacterial treatment suspensions, aliquots of bacterial culture were centrifuged at $7750 \times g$ for $10 \mathrm{~min}$ and the bacteria were then resuspended and diluted in autoclaved artificial seawater. This suspension was then passed through a glass fibre filter (2.7 $\mu \mathrm{m}$ pore size) which removed clusters and left almost exclusively single bacterial cells, as determined by microscopic examination of 2 filtered samples. Preparation procedures were aimed at producing approximate rather than exact bacterial concentrations. Each day, twice the required amount of bacterial suspension was prepared, half of which was used to prepare the control treatment solution.

Control treatment solutions were obtained by filtering half of the bacterial treatment suspension through a $0.22 \mu \mathrm{m}$ membrane, thereby standardizing the initial content of dissolved materials, including DOM, among these 2 treatments. Since larval cultures were not axenic, however, some bacteria were inevitably transferred with the larvae into the control treatment. To minimize bacterial content and growth in the control treatment, 4 steps were taken: (1) larvae were rinsed in a bath of FSW on the first day of the experiments, just before transferring them to the treatment suspensions, (2) treatment suspensions were prepared with autoclaved artificial seawater, made with reagent grade chemicals and distilled water, to minimize the availability of nutrients, (3) all material coming into contact with treatment suspensions was rinsed in distilled water and either autoclaved daily or kept in an oven at $75^{\circ} \mathrm{C}$, (4) treatment suspensions and culture trays or beakers were replaced daily. The same procedures were also repeated for bacteria and phytoplankton treatments to standardize their effects.

Expt 1: growth of Hydroides elegans. This first experiment examined whether $H$. elegans larvae could obtain sufficient energy and nutrients from bacteria to support growth. Cell concentrations in the bacterial treatment were set at high levels $\left(\sim 1.5 \times 10^{7}\right.$ cells $\left.\mathrm{ml}^{-1}\right)$. Larvae were placed in four 6 -well trays (Corning ${ }^{\circledR}$ \#25810), each treatment occupying 2 replicate wells per tray, for a total of 8 replicate wells per treatment. Each well received 4 to 6 larvae in $4 \mathrm{ml}$ of treatment suspension. After 3 d, 3 larvae were haphazardly collected from each well (i.e. 24 larvae per treatment), anaesthetized, and measured (body length) using a compound microscope. Larval size at the start of the experiment had been determined by measuring a set of 24 larvae on the first day.

Expt 2: survival and development of Hydroides elegans. The goal of the second experiment with $H$. 
elegans was to examine the implications for larval survivorship of having bacteria as the sole source of particulate food. On the seventh day of the experiment, larvae in the phytoplankton and bacterial treatments began attaching to the surface of the treatment wells, allowing the additional determination of the proportion of individuals developing to competence. Cell concentrations in the bacteria treatment were set at $\sim 4 \times$ $10^{6}$ cells $\mathrm{ml}^{-1}$, comparable to the highest concentrations observed in the field (see 'Results').

For this experiment, larvae were placed in three 6well trays, each treatment occupying 2 replicate wells per tray, for a total of 6 replicates per treatment. Each well received 10 larvae in $4 \mathrm{ml}$ of treatment suspension. Survivorship and attainment of competence (attachment not artificially induced) by larvae within each well were determined daily, prior to transferring the live larvae to new trays. On Day 9, the remaining larvae were tested for competence by transferring them to Falcon ${ }^{*}$ \#1006 petri dishes in $5 \mathrm{ml}$ of a $0.022 \mathrm{~g}$ $\mathrm{l}^{-1}\left(10^{-4} \mathrm{M}\right)$ solution of isobutyl methylxanthine (IBMX) in FSW (Bryan et al. 1997). Individuals in these dishes were re-examined $24 \mathrm{~h}$ later and were recorded as competent if they had attached to the surface, Iost their ciliated ring, and begun developing tentacles.

Expt 3: development time, size at competence, and postlarval development of Hydroides elegans. The first part of this experiment examined larval development time and body size at competence of $H$. elegans in moderate bacterial concentrations. Cell concentrations in the bacteria treatment were set at $\sim 1$ to $2 \times$ $10^{6}$ cells $\mathrm{ml}^{-1}$, comparable to concentrations commonly observed at our field sites (see 'Results'). Larvae were placed in $100 \mathrm{ml}$ glass beakers, 3 replicate beakers per treatment. Beakers each contained 200 larvae in $60 \mathrm{ml}$ of treatment suspension. Each day, larvae were gently removed from the suspensions using $25 \mu \mathrm{m}$ Nitex ${ }^{\circledR}$ screens, rinsed in 2 baths of FSW, and resuspended in new beakers containing new treatment suspensions. Larvae were inspected daily until some individuals developed elongated, flexible bodies characteristic of competent larvae; this first occurred in the phytoplankton treatment on Day 6. Once a day, starting on Day 6, a subsample of larvae from each beaker were tested for competence. To test for competence, 10 larvae were transferred from each beaker into separate Falcon ${ }^{\otimes}$ \#1006 petri dishes containing $5 \mathrm{ml}$ of IBMX solution; individuals were re-examined after 24 h for attachment and metamorphosis. Attachment of larvae within culture beakers was also recorded daily. Body lengths of 15 larvae from the phytoplankton treatment were measured on Day 7 , when a large proportion of individuals in this treatment had reached competence. A set of larvae from the bacteria and control treatments were measured on Day 11, when the proportion of competent larvae in the bacteria treatment had peaked; by that time all individuals in the phytoplankton treatment had either metamorphosed or died.

The second part of Expt 3 examined whether individuals that used bacteria as sole particulate food source during the larval phase could then develop normally as juveniles and adults. On Day 11 of Expt 3, culture beakers of the bacteria treatment on which a total of 77 Hydroides elegans had attached over the previous $24 \mathrm{~h}$ were set aside and provided with Isochrysis galbana every 2 to $4 \mathrm{~d}$. After $25 \mathrm{~d}$, the beakers were emptied to check individuals for maturity. Gametes were obtained, the procedure for fertilization described in the section 'Study organisms and general methods' was applied, and the larvae were reared using $I$. galbana as food.

Expt 4: survival and growth of Balanus amphitrite. The fourth experiment examined whether $B$. amphitrite larvae could obtain energy and nutrients from bacteria to support growth and survival. For this purpose, bacterial suspensions were prepared to high concentrations, at $\sim 4 \times 10^{6}$ cells $\mathrm{ml}^{-1}$, comparable to the highest bacterial concentrations observed in the field (see 'Results'). Stage 2 nauplii were placed in three 6well trays, each treatment occupying 2 replicate wells per tray, for a total of 6 replicates per treatment. Each well received 10 larvae in $8 \mathrm{ml}$ of treatment suspension (i.e. 60 larvae per treatment). Observations of survivorship and swimming activity were recorded daily. The stage of larval development was determined for individuals found dead on Day 8 and for all those remaining on Day 9.

\section{RESULTS}

\section{Bacterial concentrations}

Field concentrations. Average bacterial concentrations in Port Shelter ranged from 0.63 to $3.94 \times 10^{6}$ cells $\mathrm{ml}^{-1}$ (Fig. 2). The single highest value was $4.22 \times 10^{6}$ cells $\mathrm{ml}^{-1}$ observed in the offshore area in April, whereas the lowest recorded concentration was $0.47 \times$ $10^{6}$ cells $\mathrm{ml}^{-1}$ in the nearshore area in March. Seventyeight percent of bacterial concentration values recorded over the 9 mo observation period were within the range 1 to $3 \times 10^{6}$ cells $\mathrm{ml}^{-1}$.

Concentrations in treatment suspensions. In Expt 1 , a single determination of initial bacterial concentration, before adding larvae, was carried out for the bacteria treatment suspension. Concentration in this suspension was $1.6 \times 10^{7}$ bacteria $\mathrm{ml}^{-1}$. In Expts 2 and 4 , initial cell concentrations in the bacteria treatment suspensions were 4 to $5 \times 10^{6}$ cells $\mathrm{ml}^{-1}$ (Fig. 3). Bacteria 

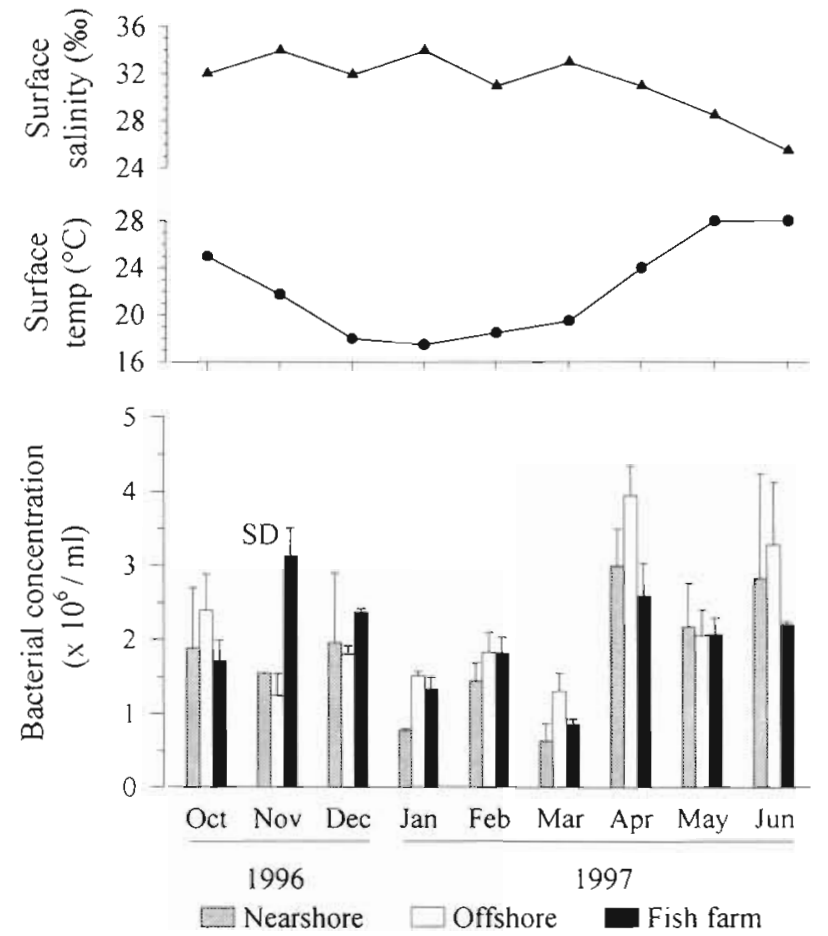

Fig. 2. Bacterial concentrations determined for surface seawater samples from 3 areas of Port Shelter, Hong Kong. Also shown are monthly surface salinities and seawater temperatures at Stn S1. All samples and measurements were taken at a depth of 20 to $40 \mathrm{~cm}$ below the surface

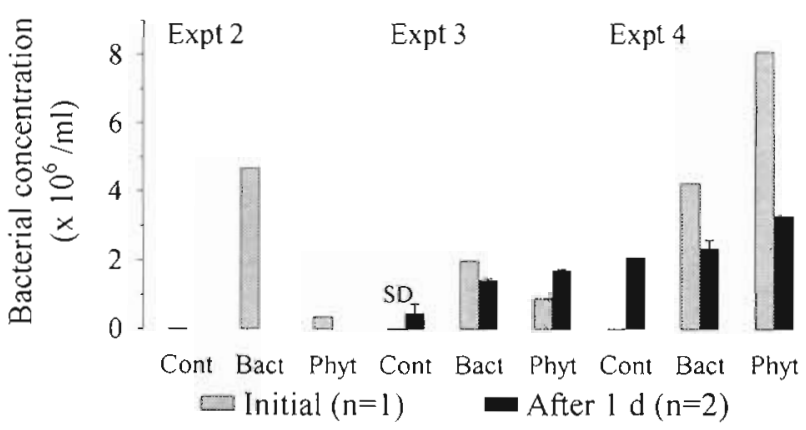

Fig. 3. Average bacterial concentrations in control, bacteria, and phytoplankton suspensions of Expts 2, 3, and 4. For each of these experiments, bacterial concentrations were determined once prior to adding larvae ('initial' values). For Expts 3 and 4 , concentrations were also determined a second time after the larvae had spent $24 \mathrm{~h}$ in the suspensions ('after $1 \mathrm{~d}$ ' values)

treatment suspensions in Expt 3 were further diluted, resulting in a concentration measurement of $1.98 \times$ $10^{6}$ cells $\mathrm{ml}^{-1}$ (Fig. 3), comparable to concentrations observed in the field during much of the year. In Expts 3 and 4, cell concentrations in the bacteria treatment after $1 \mathrm{~d}$ with larvae were lower than initial concentrations, whereas moderate bacterial growth was apparent in the controls.



Fig. 4. Hydroides elegans. Average body lengths of trochophore larvae at the start of Expt 1 (initial size), and after $3 \mathrm{~d}$ in each of the 3 treatments. All values were significantly different from each other, as determined by a Tukey multiple comparisons test at $\alpha=0.05$

\section{Expt 1: growth of Hydroides elegans}

Average body lengths of larvae at the start of the experiment and $3 \mathrm{~d}$ later in the 3 treatments differed significantly (nested ANOVA, with replicate wells as nesting factor; $\mathrm{p}<0.0001, \mathrm{n}=96$ ). Individuals in each treatment grew to different sizes over the $3 \mathrm{~d}$ period (Fig. 4), with larvae in the bacteria treatment reaching smaller sizes than those in the phytoplankton treatment (Tukey multiple comparisons test, $\alpha=0.05$ ). In addition, larvae in each treatment, including the control, had significantly larger bodies than at the start of the experiment.

\section{Expt 2: survival and development of Hydroides elegans}

Survivorship in the bacteria and phytoplankton treatments was relatively stable and remained above $85 \%$ (Fig. 5A), whereas survivorship in the control decreased gradually after Day 3 . The increased mortality in the controls after Day 8 corresponded to a drop in swimming activity in these larvae. On Day 10 , the last day of the experiment, differences in survivorship among treatments were slightly above the 5\% significance level (complete block ANOVA on arcsin transformed data, $\mathrm{p}=0.056, \mathrm{n}=18$; Zar 1984).

Many larvae in the bacteria and phytoplankton treatments reached competence during the experiment and attached to the surfaces of the treatment wells. Attachment began on Day 7 in both the phytoplankton and the bacteria treatments (Fig. 5B). Cumulative attached individuals (i.e. total attached since the beginning of the experiment) differed significantly among the 3 treatments on Day 7 (Friedman's test, $\chi_{r}^{2}=$ 


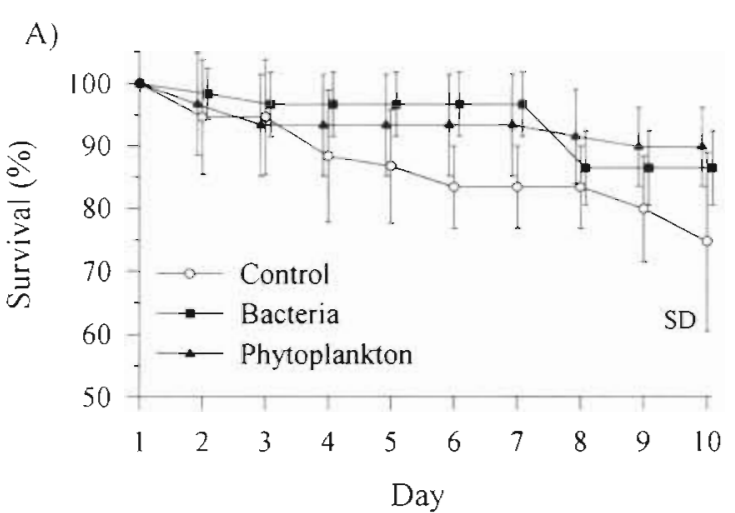

B)

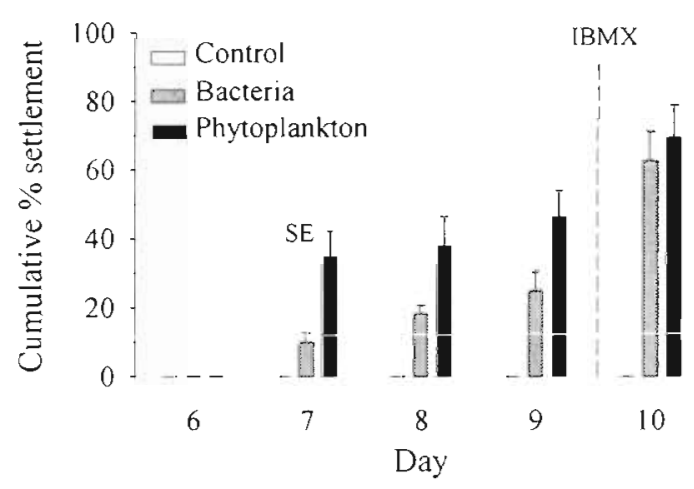

Fig. 5. Hydroides elegans. (A) Survivorship of larvae in Expt 2. (B) Cumulative percentage of larvae in Expt 2 that attached to the surfaces of the culture trays. On Day 9, the remaining larvae were tested for competence with a $10^{-4} \mathrm{M}$ solution of IBMX (see text); values for Day 10 are also cumulative, and include individuals attaching in the IBMX assay and those that had previously attached to the culture trays

12.67, $\mathrm{p}<0.005, \mathrm{n}=18$; Zar 1984) and on Day $10\left(\chi_{r}^{2}=\right.$ 23.68, $\mathrm{p}<0.001, \mathrm{n}=18$ ). Nonparametric multiple comparisons, to determine which pairs of treatments differed, could not be performed due to insufficient sample sizes (Gibbons 1993). Nevertheless, attachment of larvae on Day 7 in the phytoplankton treatment was 3.5 times higher than in the bacteria treatment. On Day 10, after the larvae remaining on Day 9 had been placed in IBMX for $24 \mathrm{~h}$, the cumulative number of attached larvae was similar in bacteria and phytoplankton treatments and there was substantial overlap of the standard errors for these 2 treatments (Fig. 5B). Larvae in the phytoplankton treatment therefore appear to have developed slightly faster than those in the bacteria treatment, but by Day 10 similar proportions of individuals in the 2 treatments had reached competence. Larvae in the control treatment did not attach nor did they develop the elongated body form observed in larvae reaching competence in the other treatments.
Expt 3: development time, size at competence, and postlarval development of $H y d r o i d e s$ elegans

The first larvae to reach competence in the bacteria treatment did so by Day 8 (Fig. 6A). During the following $24 \mathrm{~h}$, larvae in the bacteria treatment also began attaching to surfaces of the culture beakers. Percent competence in the bacteria treatment peaked on Day 11 at $57 \%$. By comparison, larvae in the phytoplankton treatment first became competent on Day 6 and individuals were found attaching to the phytoplankton culture beakers the same day. Percent competence in the phytoplankton treatment peaked on Day 8 at $87 \%$. Development of larvae provided with moderate bacterial concentrations was therefore 2 to $3 \mathrm{~d}$ slower than those provided with abundant phytoplankton. In addition, the body length of larvae in the bacteria treatment on Day 11 was on average $18 \%$ smaller than that in the phytoplankton treatment on Day 8 (Fig. 6B), although the difference was not quite significant (nested ANOVA, $F=6.31, \mathrm{p}=0.087, \mathrm{n}=34$ ). Larvae in the controls did not reach competence nor did they develop the body length or form observed in larvae reaching competence in other treatments.

For individuals from the bacteria treatment that attached to the culture beakers and were then reared
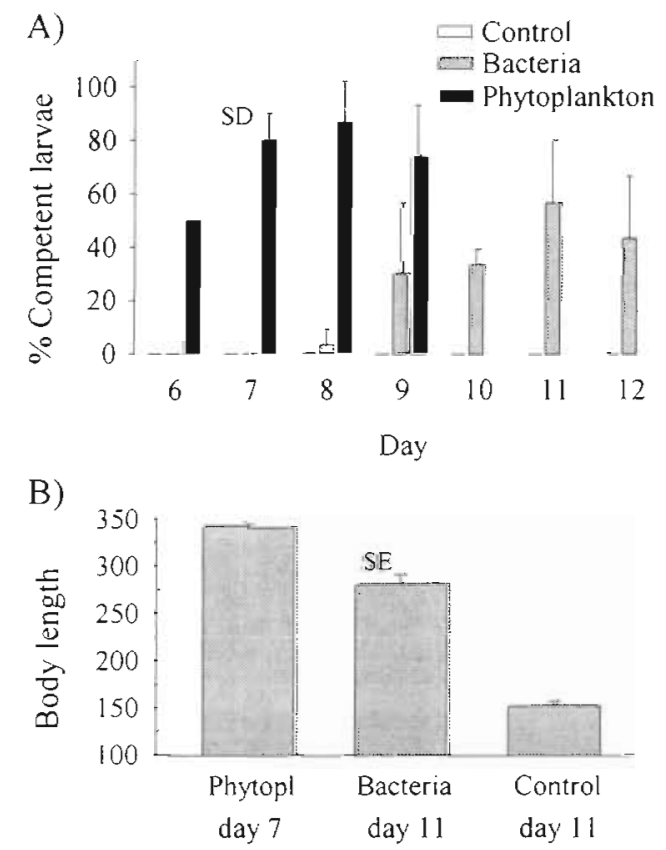

Fig. 6. Hydroides elegans. (A) Percent competent larvae (noncumulative) as determined daily in Expt 3 using the IBMX assay (see text). (B) Average body length of larvae on the day of peak percent competence: Day 7 in the phytoplankton treatment, Day 11 in the bacteria treatment. Larvae in the control were also measured on Day 11, although none had reached competence 
with Isochrysis galbana, postlarval survivorship could not be determined because some individuals detached from the glass surfaces of the beakers and were lost during periodic seawater changes. Nevertheless, $-50 \%$ of individuals were still present and alive $25 \mathrm{~d}$ after attaching to the beakers. On that day, virtually all individuals spawned spontaneously and profusely during the first $\sim 10 \mathrm{~min}$ of emersion. Samples of these gametes successfully fertilized and produced larvae which developed to competence and attached to their culture beaker after $5 \mathrm{~d}$ using $I$. galbana as food. Although fertilization success was not quantified, many larvae were obtained and thousands developed to competence, comparable to what we regularly obtain with gametes from field collected adults.

\section{Expt 4: survival and growth of Balanus amphitrite}

Survivorship of Balanus amphitrite larvae in the control and bacteria treatments was similar, decreasing after Day 5 and dropping to less than $22 \%$ by Day 9 (Fig. 7A). In the phytoplankton treatment, however, little mortality occurred during the experiment. These patterns in survivorship are consistent with observations of swimming activity, with larvae in the control and bacteria treatments becoming considerably less active beyond Day 5 and remaining on the bottom of the trays, whereas most individuals in the phytoplankton treatment swam actively throughout. Barnacle larvae in the bacteria and control treatments did not moult; all individuals remained at the nauplius II stage (Fig. 7B). All larvae in the phytoplankton treatment, however, moulted at least once, and most individuals had reached nauplius V or VI by Day 9 .

\section{DISCUSSION}

\section{Bacterivory}

At bacterial concentrations comparable to those commonly observed in the field, Hydroides elegans larvae were able to obtain enough energy and nutrients to support survival and growth. Bacterivory by $H$. elegans larvae was confirmed by observations of individuals from bacteria treatments under a compound microscope: these larvae had distended guts containing translucent white material, similar in colour to centrifuged bacteria pellets. To our knowledge this is the first record of bacterivory by a trochophore larvae. The most significant finding of this study is that $H$. elegans can complete larval development, attach, and metamorphose into healthy early juveniles in the absence of phytoplankton by using bacteria as food. This is the
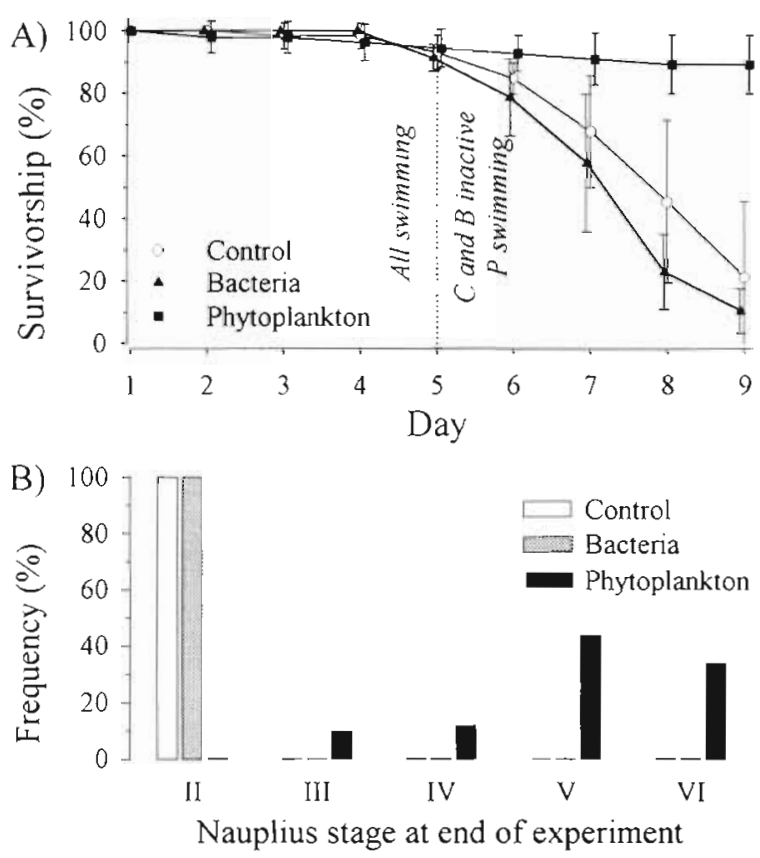

Fig. 7. Balanus amphitrite. (A) Survivorship of larvae in Expt 4. Vertical dotted line indicates the time when swimming activity decreased noticeably in control and bacteria treatments. (B) Frequency distribution of larval stages at the end of Expt 4; shown are pooled data from individuals found dead on Day 8 and from all remaining individuals on Day 9

first study to demonstrate full larval development, attachment and metamorphosis by planktotrophic larvae using bacteria as sole source of particulate food. In addition, the subsequent normal development of these juveniles in Expt 3 confirmed that $H$. elegans which have used bacteria as sole source of particulate food during the larval phase can metamorphose into healthy juveniles and subsequently develop to maturity and spawn viable offspring.

Hydroides elegans larvae readily consumed phytoplankton when available, as was apparent from the yellow-green colour of the gut and enhanced growth and development of individuals provided with Isochrysis galbana. Since bacteria were also present in the phytoplankton treatment, this suggests that $H$. elegans larvae either preferred I. galbana over the bacterial strains present in the cultures, or that food particles were consumed as they were encountered. Since phytoplankton is rarely absent in the field, larvae may use bacteria mainly as a dietary complement rather than an exclusive source of particulate food.

Balanus amphitrite, on the other hand, did not acquire detectable benefits from bacteria. Even at concentrations of bacteria that were high relative to local field conditions, barnacle larvae did not grow and their survival was similar to that of starved larvae. In addition, barnacle larvae in the bacteria treatment did not 
accumulate particulate material in their gut, as determined by observations with a compound microscope. These results are consistent with previous studies showing that barnacle larvae are unable to use or inefficient at using small phytoplankton cells as food (reviewed by R. R. Strathmann 1987), and suggest that $B$. amphitrite larvae are unable to capture bacteria.

Planktotrophic larvae therefore vary considerably in their ability to use bacteria as food, with Hydroides elegans and Balanus amphitrite representing extreme types. Intermediate types would also exist according to reports that certain bivalve larvae can obtain enough energy and nutrients from bacteria to cover part but not all of metabolic requirements (Mulinia lateralis: Chalermwat et al. 1991; Crassostrea gigas: Douillet 1993b).

\section{Ecological implications}

Hydroides elegans larvae that were provided with bacteria at concentrations similar to that commonly uccurring in ihe field grew more slowiy and reached competence later than did those provided with an abundant supply of phytoplankton. Bacterial abundances in Port Shelter, therefore, would not sustain maximum growth rates of $H$. elegans larvae. $H$. elegans larvae did, however, reach the early juvenile phase even in the absence of phytoplankton, indicating that they might not depend on phytoplankton for successful development. Whether bacteria are sufficient as the sole source of particulate food in the field will partly depend on the size range of available bacteria. Cell sizes of bacteria from the field and in experimental suspensions were not measured, but bacteria reared in the laboratory can attain larger sizes than in the field (Lee \& Fuhrman 1987). Consequently, bacterial availability to larvae in experimental suspensions may have been higher than is suggested by cell concentrations alone.

Field culturing experiments with Acanthaster planci larvae found that larvae survived well and developed at near-maximal rates at phytoplankton levels previously believed to be below the minimum threshold for this species (Olson 1987). The use of non-phytoplanktonic food sources, including bacteria, was proposed as a possible explanation for these results, which suggest that starvation may not be an important cause of mortality in $A$. planci larvae. Our results suggest starvation is unlikely to be a direct cause of larval mortality in Hydroides elegans as well, but that starvation during periods of low phytoplankton levels cannot be excluded for Balanus amphitrite.

During most of the year, phytoplankton concentration in Hong Kong waters remains $\leq 10^{3}$ cells $\mathrm{ml}^{-1}$ (Chiu et al. 1994, Qiu \& Qian 1997a and references therein): such concentrations are insufficient to support either Hydroides elegans or Balanus amphitrite larval development (Qiu \& Qian 1997a, b). However, during a 2 yr study of phytoplankton in Tai Tam Bay, $15 \mathrm{~km}$ from Port Shelter, phytoplankton abundance peaked in mid to late summer for a period $<2$ mo (Chiu et al. 1994). Correspondingly, most barnacle recruitment in Port Shelter occurs in late summer (species not identified; Qian unpubl. data). Recruitment of $H$. elegans in Port Shelter, however, occurs throughout the year, with increased attachment to experimental panels observed during the late winter and spring (Qian unpubl. data), suggesting that spawning and successful larval development are independent of phytoplankton availability. In fact, larval survival and development of $H$. elegans during the summer can be negatively affected by the reduced salinities occurring at that time (Fig. 2) due to the summer monsoon (Qiu \& Qian 1997a). Although phytoplankton might constitute a better food source for $H$. elegans than bacteria, any advantages of increased phytoplankton availability in the summer could be modest reiative to negative effects of other tactors such as reduced salinity.

Even in regions where phytoplankton availability reaches high levels, pronounced spatial and temporal variations in phytoplankton availability are common (Cloern 1991, Pae \& Yoo 1991, Pitcher et al. 1991, Ziemann et al. 1991, Litaker et al. 1993). Bacteria, on the other hand, can be present at relatively high concentrations $\left(\geq 10^{6}\right.$ cells $\mathrm{ml}^{-1}$ ) throughout the year (Rivkin et al. 1986, Turley 1993, present study), with concentrations in eutrophic coastal regions reaching up to $10^{7}$ cells $\mathrm{ml}^{-1}$ (cf. Douillet 1993a). Since gaps in feeding can negatively affect larval development (Lang \& Marcy 1982, Wehrtmann 1991, Qian \& Chia 1993, Qiu et al. 1997, Pechenik \& Qian in press, Qian \& Pechenik in press), larvae could benefit significantly by supplementing their food intake with bacteria when phytoplankton is less available or even use bacteria alone when phytoplankton is scarce.

Acknowledgements. We thank S. Lau for providing original stocks of the 4 bacterial strains used in the present study, and $\mathrm{S}$. Chiu and L. Soo for technical support. Thanks also to $\mathrm{L}$. McEdward and to 4 anonymous reviewers for providing valuable comments on previous versions of the manuscript. This work was supported by RGC grant HKUST 574/95M and Croucher Foundation grant CF94/95.SC17 to P.Y.Q. L.A.G. was supported by a postdoctoral fellowship from the Department of Biology, HKUST, and DAG grants to P.Y.Q.

\section{LITERATURE CITED}

Baldwin BS, Newell RIE (1991) Omnivorous feeding by planktotrophic larvae of the eastern oyster Crassostrea virginica. Mar Ecol Prog Ser 78:285-301 
Baldwin BS, Newell RIE (1995) Relative importance of different size food particles in the natural diet of oyster larvae (Crassostrea virginica). Mar Ecol Prog Ser 120:135-145

Bidwell JP, Spotte S (1985) Artificial seawaters: formulas and methods. Jones and Bartlett Publishers, Boston

Bryan PJ, Qian PY, Kreider JL, Chia FS (1997) Induction of larva settlement and metamorphosis by pharmacological compounds in the serpulid polychaete Hydroides elegans. Mar Ecol Prog Ser 146:81-90

Chalermwat K, Jacobsen TR, Lutz RA (1991) Assimilation of bacteria by the dwarf surf clam Mulinia lateralis (Bivalvia: Mactridae). Mar Ecol Prog Ser 71:27-35

Chiu HMC, Hodgkiss IJ, Chan BSS (1994) Ecological studies of phytoplankton in Tai Tam Bay, Hong Kong. Hydrobiologia 273:81-94

Cloern JE (1991) Tidal stirring and phytoplankton bloom dynamics in an estuary. J Mar Res 49:203-221

Costlow JD, Bookhout CG (1958) Larval development of Balanus amphitrite var. denticulata Broch reared in the laboratory. Biol Bull Mar Biol Lab Woods Hole 114:284-295

Crisp DJ, Yule AB, White KN (1985) Feeding of oyster larvae: the functional response, energy budget and a comparison with mussel larvae. J Mar Biol Assoc UK 65:759-783

Douillet P (1993a) Bacterivory in Pacific oyster Crassostrea gigas larvae. Mar Ecol Prog Ser 98:123-134

Douillet P (1993b) Carbon contribution through bacterivory in larvae of the Pacific oyster Crassostrea gigas. Mar Ecol Prog Ser 102:303-314

Douillet P, Langdon CJ (1993) Effects of marine bacteria on the culture of axenic oyster Crassostrea gigas (Thunberg) larvae. Biol Bull (Woods Hole) 184:36-51

Gibbons JD (1993) Nonparametric statistics: an introduction. Sage University paper series on quantitative applications in the social sciences, 07-090. Sage Publications, Newbury Park, CA

Hadfield MG, Unabia CC, Smith CM, Michael TM (1994) Settlement preferences of the ubiquitous fouler Hydroides elegans. In: Thompson MF, Nagabhushanam R, Sarojni R, Fingerman M (eds) Recent developments in biofouling control. AA Balkema, Rotterdam, p 65-74

Hoegh-Guldberg O (1994) Uptake of dissolved organic matter by larval stage of the crown-of-thorn starfish Acanthaster planci. Mar Biol 120:55-63

Jaeckle WB, Manahan DT (1989) Amino acid uptake and metabolism by larvae of the manne worm Urechis caupo (Echiura). a new species in axenic culture. Biol Bull (Woods Hole) 176 : $317-326$

Lang WH, Marcy M (1982) Some effects of early starvation on the survival and development of barnacle nauplii, Balanus improvisus (Darwin). J Exp Mar Biol Ecol 60:63-70

Lee S, Fuhrman JA (1987) Relationships between biovolume and biomass of naturally derived marine bacterioplankton. Appl Environ Microbiol 53:1298-1303

Litaker W, Duke CS, Kenney BE, Ramus J (1993) Short-term environmental variability and phytoplankton abundance in a shallow tidal estuary. II. Spring and fall. Mar Ecol Prog Ser 94:141-154

Martin YP, Mengus BM (1977) Utilisation de souches bacténennes sélectionnées dans l'alimentation des larves de Mytilus galloprovincialis (LMK) (Mollusque bivalve) en élevages expérimentaux. Aquaculture 10:253-262

Morton B, Morton J (1983) The sea shore ecology of Hong Kong. Hong Kong University Press, Hong Kong

Okaji K, Ayukai T, Lucas JS (1997) Selective feeding by larvae of the crown-of-thorn starfish, Acanthaster planci (L.). Coral Reefs 16:47-50
Olson RR (1987) In situ culturing as a test of the larval starvation hypothesis for the crown-of-thorn starfish, Acanthaster planci. Limnol Oceanogr 32:895-904

Pae SJ, Yoo SJ (1991) Short term variability of the phytoplankton populations in Masan Bay: I. Dynamics. $J$ Oceanol Soc Korea 26:67-76

Pearse JS, Bosch I, Pearse VB, Basch LV (1991) Differences in feeding on algae and bacteria by temperate and antarctic sea star larvae. Antarct J US 26:170-172

Pechenik JA, Qian PY (in press) Onset and maintenance of metamorphic competence in the marine polychaete Hydroides elegans in response to three chemical cues. J Exp Mar Biol Ecol

Phillips NW (1984) Role of different microbes and substrates as potential suppliers of specific, essential nutrients to marine detritivores. Bull Mar Sci 35:283-298

Pitcher GC, Walker DR, Mitchell-Innes BA, Moloney CL (1991) Short-term variability during an anchor station study in the southern Benguela upwelling system: phytoplankton dynamics. Prog Oceanogr 28:39-64

Qian PY, Chia FS (1990) Detritus as a potential food source for polychaete larvae. J Exp Mar Biol Ecol 143:63-71

Qian PY, Chia FS (1993) Larval development as influenced by food limitation in two polychaetes: Capitella sp. and Polydora ligni Webster. J Exp Mar Biol Ecol 166:93-105

Qian PY, Pechenik JA (in press) Effects of delayed larval metamorphosis and starvation on post-metamorphic growth and survival in the tube-dwelling polychaete Hydroides elegans. J Exp Mar Biol Ecol

Qiu JW, Gosselin LA, Qian PY (1997) Effects of short-term variation in food availability on larval development in the barnacle Balanus amphitrite amphitrite. Mar Ecol Prog Ser 161:83-91

Qiu JW, Qian PY (1997a) Combined effects of salinity, temperature and food on early development of the polychaete Hydroides elegans. Mar Ecol Prog Ser 152:79-88

Qiu JW, Qian PY (1997b) Effects of food availability, larval source and culture method on larval development of Balanus amphitrite amphitrite Darwin: implications for experimental design. J Exp Mar Biol Ecol 217:47-61

Rivkin RB, Bosch l, Pearse JS, Lessard EJ (1986) Bacterivory: a novel feeding mode for asteroid larvae. Science 233: $1311-1314$

Strathmann MF (1987) Reproduction and development of marine invertebrates of the Northern Pacific coast. University of Washington Press, Seattle

Strathmann RR (1987) Larval feeding. In: Giese AC, Pearse JS, Pearse VB (eds) Reproduction of marine invertebrates, Vol 9. Blackwell Scientific Publications, Palo Alto, p 465-550

Suzuki MT, Sherr EB, Sherr BF (1993) DAPI direct counting underestimates bacterial abundances and average cell size compared to AO direct counting. Limnol Oceanogr 38:1566-1570

Turley CM (1993) Direct estimates of bacterial numbers in seawater samples without incurring cell loss due to sample storage. In: Kemp PF, Sherr BF, Sherr EB, Cole JJ (eds) Handbook of methods in aquatic mıcrobial ecology. Lewis Publishers, Boca Raton, p 143-147

Wehrtmann IS (1991) How important are starvation periods in early larval development for survival of Crangon septemspinosa larvae? Mar Ecol Prog Ser 73:183-190

Zar JH (1984) Biostatistical analysis, 2nd edn. Prentice-Hall, Englewood Cliffs, NJ

Ziemann DA, Conquest LD, Olaizola M, Bienfang PK (1991) Interannual variability in the spring phytoplankton bloom in Auke Bay, Alaska, Mar Biol 109:321-334 